\title{
Analytické teorie metafory: I. Počátky interakční teorie u I. A. Richardse
}

\author{
Analytic Theories of Metaphor: I. Origins \\ of the Interaction Theory in I. A. Richards
}

Jakub Mácha

Předložená trojdílná série představuje základní teorie metafory v analytické filosofii: Tato první část osvětlí počátky interakční teorie u I. A. Richardse, jak ji podal v knize The Philosophy of Rhetorics (1936), část druhá v př́šstím čísle pak dnes již klasické podání interakční teorie u M. Blacka (1954-79) a konečně část třetí představí kritiku interakční teorie od D. Davidsona a jeho kauzální teorii (1978). Tyto tři teorie metafory vznikly sice již v průběhu minulého století, jsou ale i nadále hojně diskutovány, a tak by se dalo říci, že jejich odkaz je živý i dnes. Bezpochyby platí, že většina dnešních úvah o metafoře $\mathrm{v}$ analytické filosofii staví na těchto třech teoriích.

Představme si krátce tyto tři teorie. Cambridgeský filosof Ivor Armstrong Richards tvrdil, že metafora vždy obsahuje dvě myšlenky, doslovnou a metaforickou neboli tenor a vehicle. Jazykový význam metafory je výsledkem působení - interakce - mezi těmito dvěma myšlenkami. Max Black zachoval myšlenku interakce. Ta ale probíhá mezi tzv. ohniskem (focus) a jeho rámcem (frame) či - mohli bychom říct - kontextem. Doslovné významy ohniska a rámce spolu interagují neboli působí tak, že výsledný metaforický význam je aplikován na ohnisko metafory. Donald Davidson přišel s radikální myšlenkou, že pojem metaforického významu nemůže fungování metafory vysvětlit. Aby měl metaforický význam explanační hodnotu, musí být znám předem. Metafory jsou ale právě zvláštní tím, že jejich význam předem znám není. Tolik stručné nastínění teorií, jejichž představení bude následovat.

Přehledové články, které se čtenářům dostávají do rukou, vznikly mezi lety 2006 a 2008 jako př́ipravné studie k mé německé knize Analytische Theorien der 
Metapher (2010). Nejedná se o překlady částí této knihy. Korespondence předložených studií s jednotlivými kapitolami knihy je velmi volná, až stěží rozpoznatelná. Studie bylo třeba jazykově a redakčně upravit, především bylo nutné mnohdy doplnit kontext nezbytný pro pochopení všech tří teorií. Studie tak nepředpokládají u čtenáře žádné předchozí znalosti o filosofických teoriích metafory.

Do rozsáhlejších zásahů do původního textu jsem se nepouštěl. Stejně tak jsem se nepustil do zpracování dalších analytických teorií, především pragmatické teorie J. Searla (která byla v původním rukopisu naznačena jen bodově a nebylo ji možné zařadit do této série). Čtenáře tak mohu jen odkázat na zmíněnou německou knihu Analytische Theorien der Metapher. ${ }^{1}$ První dva díly, věnované interakční teorii, nezmiňují žádnou kritiku těchto přístupů. Třetí díl podává Davidsonovu kritiku interakční teorie. Pro nikoho nebude překvapením, že všechny tyto teorie byly podporovány a kritizovány mnohými autory (v rámci analytické filosofie i mimo). Pro přehledové zpracování hlavních argumentů pro a proti odkazuji na můj anglický článek „Metaphor in Analytic Philosophy and Cognitive Science“ (2019). ${ }^{2}$ Nyní už tedy následuje rukopis z roku 2006.

\section{Počátky interakční teorie u Richardse}

Bývá zvykem začínat pojednání o metafoře trefnou metaforou o ní samé, aby byl zdůrazněn reflexivní ráz celého podniku. Nevydáme se touto cestou, ale zvídavý čtenář jistě nalezne v těchto prvních větách mnoho obrazných výrazů, které dojem kruhového zdůvodnění navozují. Nelze se však uchylovat k extrémům a záměrně metafory zakazovat, jak činil Hobbes, nebo konstruovat umělé jazyky, které je vůbec nepřipouštějí.

Název interakčni teorie je mírně přehnaný. V následujícím půjde o jistý přrístup k pojetí metafory, který se tradičně nazývá interakční teorie, ale spíše se jedná o odpovědi na několik základních otázek týkajících se metafory. Pro začátek zmiňme jen dvě, které jsou nasnadě: „Co je to metafora?" „Jaký význam má metaforický výraz?“3

1 MÁCHA, Jakub. Analytische Theorien der Metapher: Untersuchungen zum Konzept der metaphorischen Bedeutung. Münster: LIT 2010.

2 MÁCHA, Jakub. Metaphor in Analytic Philosophy and Cognitive Science. Revista Portuguesa de Filosofia 2019, 75(4), 2247-2286.

3 Druhá otázka v sobě zahrnuje i tu první. Proto ji považujme za centrální problém této oblasti a teorie metafory by mohla v užším smyslu znamenat odpověd' na tuto otázku. 
Interakční teorie je nejvlivnější teorií metafory v oblasti tzv. analytické filozofie a za jejího autora je považován Max Black. Jen popis tohoto přístupu skýtá nemálo problémů, třebaže je na první pohled jednoduchý, ale čtenář přitom zapomene na esenciální rozdíl oproti tradiční substituční teorii metafory. ${ }^{4}$ Sami proponenti interakční teorie občas upadají do tohoto staršího myšlení o metafoře. Důvodem je patrně, že mnoho metafor lze pochopit ${ }^{5}$ i na základě substituční teorie.

Teorie metafory byla jedním z hlavních témat filozofického díla Maxe Blacka. Jádro jeho práce tvoří dva rozsáhlejší články z 50. a 70. let a odpověd' na článek Donalda Davidsona, který kritizoval některé pasáže. Davidson není jediným, kdo se - souhlasně či odmítavě - staví k interakčnímu pojetí metafory, některé z reakcí ještě zmíníme. Zkusme se ale časově vrátit na počátek této teorie $\mathrm{k}$ jejím zdrojům $\mathrm{v}$ díle anglického filozofa I. A. Richardse a v jeho knize The Philosophy of Rhetorics. ${ }^{6}$

Richards nejprve zvažuje, jestli je metafora speciální př́ípad nebo univerzální princip jazyka a kloní se druhé možnosti. ${ }^{7}$ Tento bod se musel dočkat náležité kritiky (i od M. Blacka), protože zastávat tezi, že vše je metaforou, je neudržitelné. Metaforou je tak všechno a nic. Nicméně tato teze - náležitě omezená - má své opodstatnění (jazykový fenomén může být chápán jako metaforický do jisté míry nebo se může historicky vyvinout z metafory). Důležitější je princip metafory, ve kterém se přímo objevuje slovo interakce.

Princip metafory: užíváme-li metaforu, máme dvě myšlenky, jež jsou zároveň aktivní a vyjádřené jedním slovem nebo frází, jejichž význam je výsledek jejich interakce. $^{8}$

4 Základní myšlenkou substituční teorie, jejichž počátky lze najít už u Aristotela, je, že v metafoře je doslovný výraz nahrazen - substituován - metaforickým výrazem, a tím je dosažen estetický, poetický či rétorický efekt.

5 Pochopit konkrétní metaforu lze ve většině případů bez jakékoliv její teorie. Ty slouží pouze k explikaci intuicí skrývajících se za tímto pochopením. Mnohé př́ípady těchto intuicí lze vysvětlit na základě některého substitučního pohledu.

6 RICHARDS, Ivor Armstrong. The Philosophy of Rhetoric. Oxford: Oxford University Press 1936.

7 "Metaphor is the omnipresent principle of language." Tamtéż, s. 93.

8 "Principle of metaphor: when we use a metaphor we have two thoughts of different things active together and supported by a single word, or phrase, whose meaning is a resultant of their interaction." Tamtéž, s. 94. 
To je ale značně obecná formulace a pod spojením „význam je výsledek jejich interakce“ se dá myslet mnohé, což částečně připouští i sám Richards:

Existuje obrovská rozmanitost těchto módů interakce mezi spolu se vyskytujícími myšlenkami...9

Důležité ale je, že interakci dvou myšlenek nemůžeme myslet jako nahrazení jedné druhou. Nebo možná přesněji: substituce jedné myšlenky za druhou je singulární případ jejich interakce. $\mathrm{V}$ každém př́ípadě tento princip metafory se musí brát spíše jako programová teze, jejíž rozpracování má teorie metafory teprve podat, a to se podařilo spíše Maxi Blackovi. Další podobná a značně vlivná formulace vyskytující se u Richardse je, že metafora v sobě zahrnuje dvě ideje, aby vyjádřila jednu. ${ }^{10}$ To dává tušit, že teze o všudypřítomnosti metafory není př́liš plausibilní. Jestliže všechna slova v sobě skýtají běžně dvě či více idejí, pak nemá smysl uvažovat stav, kdy slovo není víceznačné a charakteristické napětí metafory zmizí. Víceznačné pak budou i ideje, které obsahuje metafora. Další potíží ve výše zmíněných formulacích je značná nedůslednost a variabilita v používání základních teoretických pojmů, jako je význam, ${ }^{11}$ myšlenka, idea. Odstranit tento nedostatek se nepodařilo ani Maxi Blackovi a to přímo vedlo ke sporu s Donaldem Davidsonem o pojetí metaforického významu.

Richards ale pokročil v explikaci interakce poněkud dále. Dvě ideje skrývající se v každé metafoře nazývá tenor a vehicle. ${ }^{12}$ Bohužel nejasnosti postihují i toto základní názvosloví. Tenor je definován jako „původní idea“, „to, co je opravdu řečeno“, „primární subjekt“, „význam“; vehicle je pak vymezen jako „propůjčená idea“, „imaginovaná podstata“ (imagined nature), „metafora“. Použitím novější terminologie můžeme dodat, že tenor je doslovný význam

9 "[T]here is an immense variety in these modes of interaction between co-present thoughts [...]”, tamtéž, s. 94. (mé zvýraznění)

10 "[T]wo ideas for one." Tamtéž, s. 94.

11 Abychom Richardsovi nekřivdili, vysvětlení pojmu význam podává: “[M]eaning as the delegated efficacy of signs by which they bring together into new unities the abstracts, or aspects, which are the missing parts of their various contexts. [...] [A] word [...] means not one discrete past impression but a combination of general aspects.” Tamtéż, s. 94. Ale formulace mnoho nenapoví kromě toho, že významem není vzpomínka na minulý obraz, nýbrž spíše abstrakce či generalizace.

12 Aby nedošlo $\mathrm{k}$ pozdějším nedorozuměním, ponechme toto názvosloví v originále a takto budeme referovat nadále k pojetí I. Richardse. Možný překlad slov „tenor“ a „vehicle“ by mohl být „obsah“ a „nositel“. 
a vehicle metaforický význam. ${ }^{13}$ Richards takto omezuje metaforu na slovo či frázi, která v sobě skýtá dva významy, které spolu jistým způsobem interagují. ${ }^{14}$ Pokud jejich interakce závisí pouze na těchto dvou významech, proč je vůbec považovat za dva významy? Významem by mohla být tato dvojice spolu s vysvětlením jejich vzájemného působení, a tak by takto pojatý význam mohl být uveden i ve slovníku. Nebo jinak řečeno, proč vưbec potřebujeme dvě ideje? Stačilo by do slovníku uvést výsledek jejich interakce, nějakou třetí ideu. Metaforický výraz musí nějakým zpo̊sobem interagovat se svým okolím, kontextem, ve kterém je použit, a tato závislost u Richardse chybí nebo se skrývá v jeho rozmanitosti módů interakce.

Dvě ideje obsažené v metafoře spolu interagují na základě podobnosti. Koncept podobnosti je tradičně pokládán za základ metafory, vzpomeňme Aristotelovo „oko na podobnost“. Metafora pak slouží k poukázání na skrytou podobu dvou myšlenek či věcí. Problém je, že podobnost přisuzujeme spíše věcem než ideám či významům a k tomu tíhne posléze i Richards. Na druhé straně ale ukazuje metafory, které nelze vysvětlit tradiční substituční metodou, to jest metafory, u nichž nelze nalézt pouhou podobnost dvou věcí či myšlenek. Uved’me alespoň jeden příklad: „veselé víno“. Víno nemůže být nijak podobné něčemu veselému, například povídce, vtipu, obrázku. Správná interpretace se nabízí - víno může být veselé ve smyslu „vyvolávající veselou náladu po konzumaci“. Můžeme se ale znovu ptát: co spolu v tomto př́padě interaguje? Metaforický výraz je zde slovo „veselý“ ${ }^{15}$ Diktum Richardsova textu naznačuje, že v interakci stojí významy slov „veselý“ a „víno“, čímž (zřejmě nevědomky) směřuje $\mathrm{k}$ distinkci, kterou Max Black později nazve frame a focus. To dosvědčují i další pasáže:

13 Max Black podrobuje tuto distinkci také kritice a adaptuje ji do své terminologie, která se v zásadních bodech od Richardsovy odlišuje. K Richardsovu pojetí dodává: „But this picture of two ideas working upon each other is an inconvenient fiction. And it is significant that Richards himself soon lapses into speaking of 'tenor' and 'vehicle' as 'things' [...]." („Představa dvou idejí podporujících se navzájem je nevyhovující fikcí. A podstatné je, že sám Richards brzo sklouzává k vyjadřování se o ,tenoru“ a ,vehiclu' jako o ,věcech [ [...].") BLACK, M. Metaphor..., s. 47.

14 Odhlédněme od možnosti, že metaforou lze nazývat ten druhý, obrazný význam, jen samotný vehicle. Toto na konci svých přednášek o metafoře Richards diskutuje a upozorňuje na tuto dvojznačnost.

15 Můžeme se pokusit zachránit Richardovo pojetí tím, že necháme spolu působit dva významy celé fráze „veselé víno“: tj. doslovný význam a metaforický význam (víno činící svého konzumenta veselým). Tuto frázi ale doslovně chápat nelze, v doslovném významu se jedná o nesmysl. 
Vehicle kontroluje způsob, do něhož se tenor formuje.

Čím pečlivěji a pozorněji zkoumáme významy a implikace slov hluboký, čistý, pozuolný, silný a plný, když jsou aplikovány na proud a na mysl, tím méně podobností nacházíme mezi tenorem a vehiclem a tím více bude vehicle, řeka, nahližena jako záminka, abychom řekli o mysli něco, co nemůžeme říci o řece. ${ }^{16}$

Tady Richards mluví přímo o implikacích, které se přenášejí z jednoho významu na druhý. Tato pasáž jako by nezapadala do teoretického rámce prezentovaného výše a spíše bychom ji mohli najít jako ilustraci teorie Maxe Blacka.

Na závěr dodejme, že v jednom odstavci poukazuje Richards na důležitý aspekt metafory, který unikl mnoha následovníkům. Prakticky všechny teorie v této oblasti pracují s konceptem podobnosti, at již se jedná o podobnost věcí (referentů), významů, možných implikací. Přitom se ale zapomíná, že v metafoře je aktivní podobným zpơsobem i odlišnost, nepodobnost, která vytváří napětí, a to nás nutí interpretovat výraz metaforicky. Richardsovými slovy:

Interakce tenoru a vehiclu se nemusí týkat pouze jejich podobností. Aktivní je zde i jejich rozdílnost. [...] Obecně vzato, existuje velmi málo metafor, u nichž odlišnosti tenoru a vehiclu nejsou stejně tak důležité jako podobnosti. Určitá podobnost bude obvykle nápadným důvodem posunu, ale charakteristická modifikace tenoru, kterou vehicle způsobuje, je spíše více zapříčiněna jejich odlišnostmi než jejich podobnostmi. ${ }^{17}$

16 "The vehicle is still controlling the mode in which the tenor forms."

"The more carefully and attentively we go over the senses and implications of deep, clear, gentle, strong and full as they apply to a stream and to a mind, the less shall we find the resemblances between vehicle and tenor counting and the more will the vehicle, the river, come to seem an excuse for saying about the mind something which could not be said about the river.” RICHARDS, I. A. The Philosophy of Rhetoric..., s. 123.

17 "The interactions of tenor and vehicle may not be confined to their resemblances. There is disparity action too. [...] In general, there are very few metaphors in which disparities between tenor and vehicle are not as much operative as the similarities. Some similarity will commonly be the ostensive ground of the shift, but the peculiar modification of the tenor which the vehicle brings about is even more the work of their unlikenesses than of their likenesses." Tamtéž, s. 128. 


\section{Seznam použitých zdrojů}

BLACK, Max. Metaphor. In Models and Metaphors, Ithaca: Cornell University Press 1962.

MÁCHA, Jakub. Analytische Theorien der Metapher: Untersuchungen zum Konzept der metaphorischen Bedeutung. Münster: LIT 2010.

MÁCHA, Jakub. Metaphor in Analytic Philosophy and Cognitive Science. Revista Portuguesa de Filosofia 2019, 75(4), 2247-2286.

RICHARDS, Ivor Armstrong. The Philosophy of Rhetoric. Oxford: Oxford University Press 1936.

doc. Dr. phil. Jakub Mácha, Ph.D.

Katedra filozofie, Filozofická fakulta, Masarykova univerzita

Arna Nováka 1, 60200 Brno, Česká republika

macha@mail.muni.cz

Toto dílo Ize užít v souladu s licenčními podmínkami Creative Commons BY-NC-ND 4.0 International (https://creativecommons.org/licenses/by-nc-nd/4.0/legalcode). Uvedené se nevztahuje na díla či prvky (např. obrazovou či fotografickou dokumentaci), které jsou v díle užity na základě smluvní licence nebo výjimky či omezení př́slušných práv. 
